Tanjungpura Law Journal, Vol. 4, Issue 1, January 2020: 22 - 38

ISSN Print: 2541-0482 | ISSN Online: 2541-0490

Open Access at: http://jurnal.untan.ac.id/index.php/tlj

Article Info

Submitted: 25 September 2019

| Reviewed: 28 November 2019 | Accepted: 5 Desember 2019

\title{
PROBLEMATIKA PEMBENTUKAN RELAWAN DEMOKRASI DALAM PENYELENGGARAAN PEMILU SERENTAK 2019
}

\author{
Ardhiwinda Kusumaputra ${ }^{1}$, Endang Retnowati ${ }^{2}$, Ronny Winarno ${ }^{3}$
}

\begin{abstract}
This research is motivated by the formation of volunteer democracy, which is part of the General Election Commission's strategy to increase community participation in channeling voting rights. However, there is disharmony in the regulatory structure, especially in the aspects of the formation and position of democratic volunteers. This has an impact on aspects of its implementation, which would lead to obscurity. A comprehensive research needs to be done to trace the form of disharmony and the implications. The research method used is based on normative juridical research methods. The results of the writing review, based on the General Election Commission Letter Number: 32 / PP.08-SD / 06 / KPU / I / 2019, dated January 9, 2019, cannot be the basis for granting authority to Regency / City KPU I KIP to form volunteer democracy. This shows disharmony and is considered to be contrary to Law Number 7 of 2017 concerning General Elections. Besides, the implications of disharmony lead to the obscurity of the position of democratic volunteers, the task of democratic volunteers to the status of democratic volunteers. Therefore it is essential to conduct a comprehensive study to be the basis for future improvement in the legal system.
\end{abstract}

Keywords: democracy volunteer; disharmonization; formation and position

\begin{abstract}
Abstrak
Penelitian ini dilatari oleh pembentukan Relawan demokrasi yang merupakan bagian dari strategi Komisi Pemilihan Umum untuk meningkatkan partisipasi masyakat dalam menyalurkan hak pilihnya. Namun, pada tatanan regulasi terdapat disharmonisasi, khususnya pada aspek pembentukan dan kedudukan relawan demokrasi. Hal ini berdampak pada aspek implementasinya yang justru menimbulkan ketidakjelasan. Perlu dilakukan suatu kajian/penelitian yang komprehensif untuk menelusuri bentuk disharmonisasi tersebut dan implikasi yang ditimbulkan. Metode penelitian yang digunakan didasarkan pada metode penelitian yuridis normatif. Hasil kajian penulisan, dengan berdasar pada Surat Komisi Pemilihan Umum Nomor: 32/PP.08-SD/06/KPU/I/2019, tertanggal 9 Januari 2019, tidak dapat menjadi dasar dalam memberikan wewenang kepada KPU/KIP Kabupaten/Kota untuk membentuk relawan demokrasi. Hal tersebut menunjukkan adanya disharmonisasi, dan dianggap bertentangan dengan Undang-Undang Nomor 7 tahun 2017 tentang Pemilihan Umum. Selain itu, implikasi yang ditimbulkan atas disharmonisasi mengarah pada ketidakjelasan kedudukan relawan demokrasi, tugas relawan demokrasi hingga pada status relawan demokrasi. Oleh karena itu menjadi penting untuk dilakukan kajian secara komprehensif guna menjadi dasar dalam perbaikan tata hukum ke depan.
\end{abstract}

Kata Kunci: disharmonisasi; pembentukan dan kedudukan; relawan demokrasi

\footnotetext{
${ }^{1}$ Fakultas Hukum Universitas Wijaya Kusuma Surabaya, email:ardhiputra82@gmail.com

2 Fakultas Hukum Universitas Wijaya Kusuma Surabaya

${ }^{3}$ Fakultas Hukum Universitas Merdeka Pasuruan
} 


\section{Pendahuluan}

Sebagai sebuah negara yang berdasar pada kedaulan rakyat, maka terdapat konsekuensi dalam menentukan pemimpin, sekaligus wakil rakyat melalui mekanisme pemilihan, baik dilakukan secara langsung maupun tidak langsung. Hal tersebut juga telah diatur dalam Pasal 1 ayat (2) dan Pasal 22E Undang-Undang Dasar Negara Republik Indonesia Tahun 1945 (selanjutnya disebut UUD NRI 1945). Dasar kedaulatan rakyat, dan pelaksanaan pemilihan, turut pula dilandasi pada prinsip demokrasi, yang dipahami adanya bentuk partisipasi dari rakyatnya. Artinya, rakyat mempunyai peran dalam menentukan arah penyelenggaraan negara. ${ }^{4}$ Jika melihat pada desain kelembagaan negara, maka mekanisme pemilihan tersebut dimaksudkan untuk memilih Presiden dan Wakil Presiden, Dewan Perwakilan Rakyat, Dewan Perwakilan Daerah, Dewan Perwakilan Rakyat Daerah, hingga pada Kepala Daerah. Kesemuanya itu, dipilih dalam rangkaian agenda Pemilihan Umum (selanjutnya disebut sebagai Pemilu).

Tahun 2019, merupakan tonggak sejarah awal pula pelaksanaan Pemilu yang dilakukan secara langsung dan serentak, untuk memilih Presiden dan Wakil Presiden, serta Dewan Perwakilan

\footnotetext{
4 Jimly Asshiddiqie, 2005, Hukum Tata Negara dan Pilar-Pilar Demokrasi, Jakarta: Konsitusi Press, hal. 241
}

Rakyat (DPR), Dewan Perwakilan Daerah (DPD), hingga Dewan Perwakilan Rakyat Daerah Provinsi maupun Kabupaten/Kota (DPRD Provinsi dan Kabupaten/Kota). Apabila menelurusi dari aspek historis, jejak pemilu yang pernah dilangsungkan di Indonesia, dapat dipahami dalam beberapa periodisasi, diantaranya pemilu pertama era orde lama atau parlementer tahun 1955, era orde baru tahun 1971 - 1997 dan era reformasi tahun 1999 - 2009. ${ }^{5}$ Masing-masing periode tersebut, mempunyai karakter tersendiri dalam pelaksanaan pemilu. Pada era orde lama tahun 1955, dengan dasar sistem pemerintahan pada waktu itu masih menganut sistem parlementer, maka pemilu dilakukan hanya untuk memilih anggota DPR dan Dewan Konstituante. Periode ini sekaligus menjadi tonggak awal dilakukannya pemilu secara langsung oleh rakyat. Mekanisme tersebut juga tetap dipertahankan pada era orde baru 19711997, hanya saja tidak lagi memilih Dewan Konstituante.

Memasuki era reformasi, perubahan besar dilakukan sesuai dengan amanat perubahan konstitusi. Pemilu dilakukan secara langsung tidak hanya memilih wakil rakyat di DPR, tetapi juga adanya anggota DPD, dan pemilihan presiden serta wakil presiden.

\footnotetext{
5 Suparno, et.all., 2010, Pemilu Untuk Pemula, Jakarta: Komisi Pemilihan Umum, hal. 4
} 
Pemilihan presiden dan wakil presiden secara langsung pada tahun 2004, merupakan pemilihan awal sejak bergesernya sistem parlementer, dan penguatan supremasi konstitusi. 6 Meskipun demikian, pelaksanaan pemilu untuk anggota DPR, DPD dan DPRD (selanjutnya dapat juga disebut pemilu legislatif), dengan pemilu presiden, tidak dilangsungkan dalam waktu yang bersamaan. Mencermati pada Rapat Dengar Pendapat Umum (RDPU), yang dituangkan dalam risalah pembahasan RUU Pemilihan Presiden dan Wakil Presiden di tahun 2003, dapat diketahui dasar pertimbangan pemisahan waktu pemilihan tersebut guna mewujudkan pemilihan yang berkualitas. Disamping itu, masyarakat juga dapat lebih memahami calon / kandidat yang nantinya akan dipilih, sehingga mampu melahirkan pemilu yang kondusif.

Namun, dinamika ketatanegaraan yang terjadi sejak pelaksanaan pemilu di tahun 2004, 2009 dan 2014, turut mendorong perubahan mekanisme pemilu. Sejak diundangkannya UndangUndang Nomor 7 Tahun 2017 tentang Pemilihan Umum (selanjutnya disebut UU No. 7 Tahun 2017), maka ditetapkan pula mekanisme pemilu serentak untuk melakukan pemilu legislatif dan pemilu presiden serta wakil presiden dalam waktu yang bersamaan. Dasar

\footnotetext{
${ }^{6}$ Janedrji M. Gaffar, 2010, Hukum Acara Mahkamah Konstitusi, Jakarta: Sekretariat Jenderal dan Kepaniteraan Mahkamah Konstitusi, hal. 7
}

pertimbangan pelaksanaan pemilu serentak ini adalah untuk efisiensi anggaran, waktu, serta mencegah tindak pidana korupsi. ${ }^{7}$ Dasar tersebut juga sebagaimana yang pernah menjadi argumentasi gugatan pengujian UndangUndang Nomor 42 Tahun 2008 tentang Pemilihan Presiden, yang tertuang dalam Putusan Mahkamah Konstitusi Nomor 14/PUU-XI/2013.

Mengingat bahwa dalam sejarah pelaksanaan pemilu di Indonesia belum pernah dilangsungkan pemilu secara serentak, maka Komisi Pemilihan Umum (KPU), sebagai lembaga penyelenggara pemilu mempunyai tanggungjawab yang lebih besar untuk mensukseskan pemilu serentak 2019. Bukanlah suatu hal yang mudah bagi KPU, apalagi jika melihat data partisipasi pemilih yang "golput" (tidak memilih), mengalami kenaikan sejak pemilu di 2004. Tercatat pada tahun 2004, khususnya pada pemilu presiden dan wakil presiden, terjadi "golput" sebanyak 23,3\%, tahun 2009 sebanyak 27,45\% dan tahun 2014 sebanyak 30,42\%. Sedikit berbeda dengan pelaksanaan pemilu legislative, angka "golput" di tahun 2004 mencapai 15,93\%, tahun 2009 sebanyak 29,01\%, dan tahun 2014 mengalami penurunan angka golput yaitu $24,89 \%$.

Tantangan untuk mewujudkan pemilu yang kondusif dan partisipatif ini

\footnotetext{
${ }^{7}$ Ria Casmi Arrsa, 2014, "Pemilu Serentak dan Masa Depan Konsolidasi Demokrasi”, Jurnal Konstitusi, Vol. 11, No. 3, hal. 524
} 
berusaha dijawab oleh KPU dengan membentuk "Relawan Demokrasi", yang dibentuk dan bertugas di tiap-tiap kabupaten/kota. Secara filosofis dapat dipahami bahwa pembentukan relawan demokrasi adalah sebagai sarana dan kekuatan untuk meningkatkan partisipasi pemilih, memberikan pendidikan pemilu serta melakukan sosialisasi pemilu serentak 2019. 8 KPU kemudian mengeluarkan Surat KPU Nomor: 32/PP.08-SD/06/KPU///2019, tanggal 9 Januari 2019, perihal Pembentukan Relawan Demokrasi Pemilu Serentak Tahun 2019.

Namun jika mencermati pada tata pengaturannya (aspek yuridis), maka pembentukan relawan demokrasi ini menimbulkan disharmonisasi pengaturan. UU No. 7 Tahun 2017, tidak memberikan dasar hukum yang tertuang secara implisit maupun eksplisit atas pembentukan relawan demokrasi oleh KPU di tingkat Kabupaten/Kota. Bahkan, dalam Peraturan KPU Nomor 10 Tahun 2018 tentang Sosialisasi, Pendidikan Pemilih dan Partisipasi Masyarakat dalam Penyelenggaraan Pemilihan Umum (selanjutnya disebut Peraturan KPU No. 10 Tahun 2018), juga tidak terdapat ketentuan yang memberikan dasar hukum pembentukan relawan demokrasi oleh KPU. Apalagi, jika mencermati pada tugas yang melekat pada relawan demokrasi, yaitu

8 Komisi Pemilihan Umum, 2019, Pedoman Pelaksanaan Relawan Demokrasi (Relasi) Pemilu melakukan sosialisasi dan pendidikan pemilih adalah bentuk tugas yang diberikan (pendelegasian) oleh KPU, khususnya pada tingkat Kabupaten/Kota. Secara khusus, jika mencermati Pasal 16 Peraturan KPU No. 10 Tahun 2018, relawan demokrasi adalah sebagai subyek yang menjadi sasaran KPU dalam melakukan pendidikan pemilih. Artinya, berdasar pada ketentuan tersebut dapat dipahami jika relawan demokrasi bukanlah sebagai subyek yang melakukan sosialisasi pendidikan pemilih.

Kondisi tersebut dapat berdampak pula pada tatanan struktural eksistensi relawan demokrasi. Ketidakjelasan kedudukan dalam hirarkis kelembagaan penyelenggara pemilu, khususnya yang bersifat ad-hoc. Berbeda dengan Panitia Pemilihan Kecamatan (PPK), Panitia Pemungutan Suara (PPS), ataupun Kelompok Penyelenggara Pemungutan Suara (KPPS), yang secara yuridis, dalam UU No. 7 Tahun 2017, beserta aturan turunan lainnya dijelaskan secara tegas mengenai kedudukan, fungsi pembentukan, tugas, jangka waktu hingga pada pembubarannya. Mengingat bahwa keberadaan relawan demokrasi merupakan hal baru, khususnya pada pemilu serentak 2019, maka seharusnya perlu dikonstruksikan secara jelas mengenai kedudukannya.
Tahun 2019, Jakarta: Komisi Pemilihan Umum, hal. 1-3 
Hal ini juga berpengaruh pada tatanan pelaksanaan relawan demokrasi. Sebagai contoh yang terjadi di salah satu kabupaten, yaitu Kabupaten Pasuruan, terdapat ketidakjelasan dalam struktur dan tata laksana tugas relawan demokrasi, khususnya jika dikaitkan dengan keberadaan PPK dan PPS. Bahkan pada saat dilakukan bimbingan teknis (bimtek) relawan demokrasi dengan PPK dan PPS, masih menimbulkan pertanyaan mengenai kedudukannya. Walaupun pada akhirnya dijelaskan oleh KPU Kabupaten Pasuruan, bahwa kedudukan relawan demokrasi sejajar dengan PPK, tetap saja secara regulasi belum ada ketentuan yang secara jelas mengaturnya. Begitu juga pada saat pembentukan dan pembubaran. Surat yang dikeluarkan oleh KPU Pusat hanya mengenai pembentukan relawan demokrasi, tidak ada ketentuan atau penjelasan tentang pembubaran. Hal ini kemudian yang juga terjadi pada relawan demokrasi di Kabupaten Pasuruan, yang tidak ada mekanisme pembubaran. Tentu dalam perspektif hukum menimbulkan implikasi tersendiri, bahwa secara status ketika sudah dilakukan pembentukan, dan tidak ada mekanisme pembubaran, padahal diketahui bahwa relawan demokrasi juga bersifat ad-hoc,

9 Anwar C., 2008, Teori dan Hukum Konstitusi Paradigma Kedaulatan Pasca Perubahan UUD 1945, Implikasi dan Implementasinya Pada Lembaga Negara, Malang: In-Trans Publishing, hal. 53-54 maka sesungguhnya relawan demokrasi masih terikat hak dan kewajibannya dengan KPU Kabupaten Pasuruan. Berbeda dengan PPK dan PPS, dilangsungkan proses pembubaran dan dituangkan dalam peraturan tersendiri yang dikeluarkan oleh KPU.

Oleh karena itu, perlu kiranya untuk dilakukan evaluasi kembali, khususnya mengenai eksistensi relawan demokrasi. Meskipun secara filosofis, relawan demokrasi mempunyai hakikat dan peranan yang sangat penting, namun tetap harus memperhatikan adanya regulasi. Hal ini sejalan dengan prinsip negara hukum, maka segala bentuk penyelenggaraan negara harus berdasarkan ketentuan norma hukum (peraturan perundang-undangan). 9 Dalam penulisan ini akan membahas mengenai apakah yang menjadi problematika dalam pembentukan relawan demokrasi dalam pemilu 2019 serta implikasi dari munculnya problematika pembentukan relawan demokrasi terhadap penyelenggaraan pemilu 2019.

\section{Metode}

Pada dasarnya metode penelitian ini bersifat yuridis normatif, yaitu dilakukan pengkajian bahan kepustakaan yang bersifat hukum, dengan mengutamakan data sekunder. 10

10 Soerjono Soekanto dan Sri Mamudji, 2006, Penelitian Hukum Normatif (Suatu Tinjauan Singkat), Jakarta: PT Raja Grasindo Persada, hal. 13. 
Terdapat tiga pendekatan yang dilakukan, yaitu pendekatan peraturan perundang-undangan (statute approach), pendekatan teoritis (theoretical approach), dan pendekatan kasus (case approach). Meskipun demikian, tidak menutup kemungkinan juga melakukan kajian berdasar data primer. Nantinya data yang diperoleh, dilakukan analisis secara yuridis kuantitatif, dengan penyajian uraian deskriptif.

\section{Analisis dan Pembahasan}

A. Problematika Dasar Pembentukan Relawan Demokrasi

Secara filosofis, pemilu merupakan manifestasi dari jiwa bangsa (volksgeist). Salah satu bentuk dari prinsip kedaulatan rakyat, yang merujuk pada kekuasaan berada di tangan rakyat, dan dijalankan sesuai dengan konstitusi (hukum). Rakyat menentukan baik dan buruknya perjalanan sebuah negara, melalui mekanisme pemilihan. $\mathrm{Hal}$ ini tidak mungkin jika paham kedaulatan itu dijalankan semurni-murninya, tetap diperlukan adanya bentuk perwakilan melalui serangkaian proses pemilihan. Pada tahap pemilihan itulah, keterlibatan rakyat diperlukan agar mampu memperkuat legitimasi. Pemilu untuk kemudian menjadi sebuah sarana yang efektif untuk menjalankan kedaulatan rakyat. Menjadi sarana untuk mencapai tujuan. Pada aspek aksiologisnya, pemilu mampu memberikan keteraturan dalam membentuk dan menjalankan kekuasaan negara, serta mampu mengaktualisasikan nilai demokrasi dalam bingkai kedaulatan rakyat. Guna memberikan kepastian dan keadilan, maka secara epistimologis, perlu disusun sebuah metode dalam suatu sistem pemilu yang berintegritas dan dapat diterima serta dipahami oleh rakyatnya. ${ }^{11}$ Berdasar pada paham negara hukum, maka sistem pemilu yang disusun tersebut dituangkan dalam suatu peraturan perundang-undangan yang terkodifikasi, yaitu UU No. 7 Tahun 2017 dengan tetap berpegang pada UUD NRI 1945 sebagai sebuah konstitusi negara. Secara normatif, pada Pasal 1 angka 1 UU No. 7 Tahun 2017 ditegaskan bahwa:
Pemilihan Umum yang selanjutnya disebut Pemilu adalah sarana kedaulatan rakyat untuk memilih anggota Dewan Perwakilan Rakyat, anggota Dewan Perwakilan Daerah, Presiden dan Wakil Presiden, dan untuk memilih anggota Dewan Perwakilan Rakyat Daerah, yang dilaksanakan secara langsung, umum, bebas, rahasia, jujur, dan adil dalam Negara Kesatuan Republik Indonesia berdasarkan Pancasila dan Undang-Undang Dasar Negara Republik Indonesia Tahun 1945.

Dapat dipahami pula bahwa secara normatif, pemilu juga diartikan sebagai sebuah sarana untuk memilih wakil rakyat dan pemimpin negara, dengan berdasar pada asas langsung,

11 Tegus Prasetyo, 2018, Filsafat Pemilu, Bandung: Nusa Media, hal. 7-12. 
umum, bebas, rahasia jujur dan adil. Asas tersebut bertindak sebagai haluan atau rambu-rambu dalam menyelenggarakan pemilu. Berdasar pada pengertian normatif itu pula, maka pelaksanaan pemilu dilakukan secara bersamaan atau serentak, yaitu dengan memilih anggota legislatif baik di tingkat pusat maupun daerah, serta presiden dan wakil presiden. Penetapan pemilu serentak ini merupakan yang pertama kali dalam sejarah pelaksanaan pemilu di Indonesia sejak tahun 1955. Jika menelusuri pada risalah pembentukan undang-undang yang berkaitan dengan pemilu, maka rencana atau pembahasan pelaksanaan pemilu serentak ini dapat diketahui sejak pembahasan rancangan undangundangan pemilihan presiden dan wakil presiden pada tahun 2003. Namun, pada waktu itu masih diputuskan untuk melangsungkan pemilu secara terpisah antara anggota legislatif dengan presiden dan wakil presiden. Barulah sejak diundangkannya UU No. 7 Tahun 2017, ditetapkan untuk melakukan pemilu serentak yang dilangsungkan pada 17 April 2019.

Sebagai suatu hal yang baru, pelaksanaan pemilu serentak tahun 2019 menjadi tantangan tersendiri bagi KPU sebagai penyelenggara pemilu. KPU harus bekerja ekstra, termasuk melakukan kerja sama dan koordinasi dengan berbagai lembaga terkait, seperti kepolisian dan bawaslu, dengan maksud untuk mencegah kecurangan dan pelanggaran pemilu. Di sisi lain, KPU juga harus mampu meningkatkan partisipasi masyarakat, khususnya dalam menyalurkan hak pilihnya. Apalagi jika melihat pada pelaksanaan pemilu pada periode sebelumnya yang cenderung mengalami penurunan jumlah partisipasi pemilih.

Berdasar pada Pasal 12 huruf j, Pasal 15 huruf $\mathrm{j}$, Pasal 18 huruf $\mathrm{j}$, Pasal 53 ayat (1) huruf e, Pasal 56 huruf i UU No. 7 tahun 2017, guna meningkatkan partisipasi masyarakat, maka KPU bertugas melakukan sosialisasi pemilu, atau sosialisasi berkaitan dengan penyelenggaraan pemilu dan pendidikan pemilih. Perlu juga dipahami bahwa berdasar Pasal 6 UU No. 7 Tahun 2017, KPU terdiri atas KPU (Pusat), KPU Provinsi, KPU Kabupaten/Kota, PPK, PPS, PPLN, KPPS, dan KPPSLN. Diantara kesemuanya itu, yang secara langsung mempunyai tugas untuk melakukan sosialisasi adalah KPU Pusat sampai daerah, PPK, dan PPS. Ketentuan itu pula yang menjadi dasar pembentukan Peraturan KPU No. 10 Tahun 2018.

Atas inisiasi KPU (Pusat), dengan maksud untuk mensukseskan pemilu serentak 17 April 2019, maka melalui surat KPU Nomor: 32/PP.08SD/06/KPU/I/2019, tertanggal 9 Januari 2019, yang ditujukan kepada KPU/KIP Kabupaten/Kota, diharuskan untuk membentuk Relawan Demokrasi. Artinya, berdasar pada surat tersebut KPU/KIP 
Kabupaten/Kota bertugas untuk membentuk relawan demokrasi. Pada bagian lampiran surat, yaitu berisikan Pedoman Pelaksanaan (Relasi) Relawan Demokrasi Pemilu Tahun 2019, disebutkan dasar hukum yang dapat dipahami sebagai dasar hukum pembentukan relawan demokrasi, antara lain:

1. UU No. 7 Tahun 2017

2. Peraturan KPU Nomor 05 Tahun 2008 Tentang Tata Kerja Komisi Pemilihan Umum, Komisi Pemilihan Umum Provinsi, dan Komisi Pemilihan Umum Kabupaten/Kota, sebagaimana diubah dengan Peraturan KPU Nomor 01 Tahun 2010;

3. Peraturan KPU Nomor 06 Tahun 2008 Tentang Susunan Organisasi Dan Tata Kerja Sekretariat Jenderal Komisi Pemilihan Umum, Sekretariat Komisi Pemilihan Umum Provinsi, dan Sekretariat Komisi Pemilihan Umum Kabupaten/Kota;

4. Peraturan KPU No. 10 Tahun 2018;

5. Peraturan Menteri Keuangan Nomor 190/PMK.05/2012 Tentang Tata Cara Pembayaran Dalam Rangka Pelaksanaan Anggaran Pendapatan dan Belanja Negara;

6. Peraturan Menteri Keuangan Nomor : 32/PMK.02/2018 Tentang Standar Biaya Masukan Tahun Anggaran 2019.

$$
\text { Dapat dipahami bahwa }
$$

pembentukan relawan demokrasi adalah sebagai wujud prinsip demokrasi dalam pelaksanaan pemilu. Apalagi berdasar pada regulasi yang ada, telah mengamanatkan untuk melaksanakan pemilu secara serentak, dengan maksud meningkatkan partisipasi masyarakat.

Namun, jika berbagai dasar hukum tersebut ditelaah, tidak ditemukan satupun ketentuan (Pasal), yang memberikan dasar hukum pembentukan relawan demokrasi, baik oleh KPU (Pusat), KPU Provinsi, bahkan secara khusus oleh KPU Kabupaten/Kota. Sebagaimana telah dijelaskan pula, bahwa tugas dan tanggungjawab untuk melakukan sosialisasi mengenai pemilu, dari segala aspek, ada pada KPU. Lebih lanjut, pada Bab II Peraturan KPU No. 10 Tahun 2018 juga ditegaskan Sosialisasi Pemilu dan Pendidikan Pemilih Yang Dilaksanakan Oleh KPU, KPU Provinsi/KIP Aceh, Dan KPU/KIP Kabupaten/Kota. Berikut juga pada Pasal 5 ayat (1) Peraturan KPU No. 10 Tahun 2018 yang menegaskan sasaran pelaksanaan sosialisasi, salah satunya adalah relawan demokrasi. Artinya secara normatif (sesuai ketentuan peraturan perundang-undangan), relawan demokrasi adalah obyek sosialisasi, bukan subyek yang melakukan sosialisasi pemilu dan pendidikan pemilih.

Berdasar pada ketentuan yang ada, baik UU No. 7 Tahun 2017 hingga pada Peraturan KPU No. 10 Tahun 2018, tidak ditemukan satupun ketentuan yang benar-benar dapat dijadikan dasar, baik implisit maupun eksplisit. Ditinjau dari perspektif hukum administrasi negara, khususnya berkaitan dengan teori wewenang, maka tindakan KPU tersebut tidak dapat didasarkan pada kewenangan atribusi, delegasi, maupun juga mandat. Bahkan, tindakan tersebut dapat 
dimungkinkan sebagai suatu tindakan melampaui kewenangan (detournement de pouvoir), sebab dalam ketentuan peraturannya hanya menyebut bahwa KPU melakukan sosialisasi, namun pada pelaksanaannya KPU justru membentuk suatu badan ad-hoc yang secara khusus bertindak untuk melakukan sosialisasi pemilu dan pendidikan pemilih. Tidak boleh ada tujuan atau bentuk lain, selain daripada yang sudah ditetapkan oleh peraturan perundang-undangan. ${ }^{12}$

Berbeda dengan ketentuan mengenai pembentukan PPK dan PPS. Pada Pasal 51 ayat (3) UU No. 7 Tahun 2017, secara tegas menyatakan bahwa: "PPK dibentuk oleh KPU Kabupaten/Kota paling lambat 6 (enam) bulan sebelum Penyelenggaraan Pemilu dan dibubarkan paling lambat 2 (dua) bulan setelah pemungutan suara". Begitu juga dengan pembentukan PPS, yang diatur pada Pasal 54 ayat (3), bahwa: "PPS dibentuk oleh KPU Kabupaten/Kota paling lambat 6 (enam) bulan sebelum Penyelenggaraan Pemilu dan dibubarkan paling lambat 2 (dua) bulan setelah hari pemungutan suara". Artinya, secara atributif, terdapat legitimasi dalam hal pembentukan kedua badan ad-hoc tersebut. Terdapat ketentuan yang jelas, bahkan hingga pada janga waktu pembentukan dan pembubarannya.
Bahkan turut pula disertakan tugas dan wewenangnya, yang salah satunya juga turut melakukan sosialisasi penyelenggaraan pemilu. Menjadi relevan dan sinkron jika kemudian pada aturan yang lebih rendah, seperti Peraturan KPU, dibentuk peraturan teknis yang mengarah pada peran dari PPK dan PPS, khususnya jika dihubungkan dengan hubungan KPU.

Pada kondisi inilah muncul bentuk ketidakjelasan dasar dikeluarkannya surat KPU Nomor: 32/PP.08SD/06/KPU/I/2019, tertanggal 9 Januari 2019, khususnya dari perspektif hukum. Menjadi pertanyaan besar berkaitan dengan daya ikat dan kekuatan berlakunya, khususnya jika dihubungkan dengan UU No. 7 Tahun 2017. Sekalipun dalam Pasal 15 ayat (2) huruf $f$, disebutkan bahwa: "pendidikan pemilih dapat idlakukan melalui pembentukan agen/relawan demokrasi", tetap harus mengacu pada kesesuaian peraturan perundang-undangan. Pembentukan suatu badan atau lembaga publik (negara), baik yang bersifat permanen maupun ad-hoc, juga harus menyesuaikan dengan lingkup dan arah kinerjanya. Perlu juga diperhatikan mengenai kewenangan pembentukan lembaga, didasarkan pada undangundang dasar, undang-undang,

12 Philupus M. Hadjon, et.all., 2008, Pengantar Hukum Administrasi Indonesia, Introduction to the Indonesian Administrative Law, Yogyakarta: Gadjah Mada University Press, hal. 277. 
peraturan pemerintah atau yang lainnya, sebab terdapat kondisi tersendiri yang harus diperhatikan. ${ }^{13}$

Mencermati pada tugas, wewenang, lingkup wilayah kerja, pola hubungan dengan KPU Kabupaten/Kota, serta teknis pembentukan relawan demokrasi yang telah dituangkan dalam pedoman teknis, maupun pada pelaksanannya, maka keberadaan relawan demokrasi dapat disejajarkan dengan PPK. Bahkan hubungan antara KPU/KIP Kabupaten/Kota dengan relawan demokrasi, bersifat top-down, langsung tanpa ada perantara. Artinya, dengan adanya bentuk yang semacam itu, tidak tepat jika secara serta merta pembentukan relawan demokrasi langsung dituangkan dalam peraturan yang sebenarnya bersifat teknis dan kurang mempunyai legitimasi. Dibandingkan dengan pembentukan PPK dan PPS yang secara atributif melalui undang-undang, yaitu UU No. 7 Tahun 2017. Menjadi tidak relevan dan tidak sesuai dengan UU No. 7 Tahun 2017. Bagaimana mungkin suatu badan ad-hoc, yang lingkup kerjanya meliputi satu kabupaten/kota, mempunyai tugas dan wewenang untuk melakukan sosialisasi pemilu dan pendidikan pemilih, serta mempunyai hubungan langsung dengan KPU/KIP Kabupaten/Kota, hanya

13 Jimly Asshiddiqie, 2010, Perkembangan \& Konsolidasi Lembaga Negara Pasca Amandemen, Jakarta: Sinar Grafika, hal. 37

14 Surat Edaran Bukan Peraturan PerundangUndangan, dibentuk berdasarkan surat edaran. Mengingat bahwa dalam Peraturan KPU No. 10 Tahun 2018, tidak langsung disebutkan bahwa pembentukan relawan demokrasi dilakukan oleh KPU/KIP Kabupaten/Kota di seluruh Indonesia. Padahal PPK dan PPS yang, lingkup wilayah kerjanya lebih rendah dari relawan demokrasi, dibentuk berdasarkan undang-undang. Tentu menimbulkan disharmonisasi.

Dari perspektif teori peraturan perundang-undangan, pembentukan surat KPU Nomor: 32/PP.08SD/06/KPU/I/2019, tertanggal 9 Januari 2019, juga menimbulkan problematika ketidaksesuaian substansi dan tujuan. Pembentukan sebuah surat (termasuk surat edaran) dari lembaga negara, harus didahului dengan adanya kejelasan rumusan dalam peraturan perundangundangan, sehingga pada saat dituangkan dalam surat, sifatnya hanya mempertegas, dan memperjelas aspek operasionalnya. Adanya sebuah surat yang dikeluarkan lembaga negara, tidak boleh bertentangan dengan peraturan perundang-undangan, khususnya undang-undang, peraturan pemerintah. ${ }^{14}$ Ketika muncul surat dari KPU (pusat) yang mengharuskan KPU/KIP Kabupaten/Kota membentuk relawan demokrasi, maka secara normatif dalam

www.hukumonline.com/berita/baca/hol18765/suratedaran-bukan-peraturan-perundangundangan, diakses tanggal 16 Maret 2018 
peraturan perundang-undangan, khususnya dalam UU No. 7 Tahun 2017, sudah harus ada kewenangan untuk melakukan itu.

Sebagai sebuah perbandingan, terdapat surat KPU Nomor 241/PP.05SD/01/KPU/II/2019, tertanggal 9 Februari 2019 tentang Pembentukan Kelompok Penyelenggara Pemungutan Suara (KPPS). Secara normatif, aturan tentang pembentukan KPPS ini telah ada pada Pasal 59 UU No. 7 Tahun 2017. Artinya, pembentukan surat tersebut sudah sesuai dengan ketentuan peraturan perundangan-undangan. Surat hanya bersifat memastikan dan memberi arahan operasional. Dasar legitimasinya sudah dibentuk terlebih dahulu. Bukan kewenangan pembentukan yang didasarkan pada surat. Apalagi surat bukan masuk kategori peraturan perundang-undangan. Menjadi bertentangan dan disharmoni ketika sebuah surat justru dijadikan dasar dalam menyusun kewenangan yang sebelumnya atau pada peraturan perundang-undangan tidak ditetapkan untuk itu. Sekalipun (jika) suatu surat (dianggap) sebagai suatu aturan, tetap saja secara substansi bertentangan dengan aturan yang lebih tinggi, berlaku asas lex superior derogate legi inferior, dengan prinsip peraturan yang kedudukannya lebih tinggi, mengesampingkan peraturan yang lebih

15 Sirajuddin, et.all., 2016, Legislative Drafting, Pelembagaan Metode Partisipatif dalam rendah, khususnya jika ditemukan adanya pertentangan. ${ }^{15}$

Pada kondisi inilah penting untuk melakukan refleksi kembali, khususnya berkaitan dengan pembentukan sebuah badan ad-hoc oleh lembaga negara. Adanya disharmonisasi pengaturan ini, jelas juga menimbulkan ketidakjelasan kedudukan relawan demokrasi, khususnya secara struktural pada KPU. Terdapat petunjuk atau arahan pembentukan oleh KPU, namun keberadaannya seolah menjadi "hantu". Jangan sampai kondisi yang semacam ini justru mengakibatkan turunnya kredibilitas, dan mempertanyakan tentang profesionalitas sebuah lembaga negara yang menyelenggarakan pemilu.

\section{B. Implikasi Problematika}

Pembentukan Relawan Demokrasi

Tidak banyak pihak yang menyoroti eksistensi relawan demokrasi, khususnya dari aspek hukum kewenangan pembentukannya. Banyak pihak yang lebih berfokus pada tatanan penegakkan hukum pemilu, pelanggaran pemilu, PHPU, pemungutan dan perhitungan suara, kampanye, hingga pada masalah DPT. Padahal, mengenai kewenangan pembentukan relawan demokrasi ini, menyimpan masalah khususnya dari aspek pengaturannya, yang tentunya berdampak pula pada profesionalitas kinerja KPU sebagai sebuah lembaga negara. Penulis

Pembentukan Peraturan Perundanga-undangan, Malang: Setara Press, hal. 81 
berusaha untuk mengkaji pemilu 2019 dari sudut yang berbeda, yaitu mengenai eksistensi relawan demokrasi.

Harus diakui, bahwa tujuan pembentukan relawan demokrasi merupakan hal yang baik. Melalui adanya relawan demokrasi, setidaknya mampu berperan dalam usaha mensukseskan pemilu dengan meningkatkan partispasi masyarakat. Terbukti dengan naiknya partisipasi masyarakat yang menyalurkan hak pilihnya, mencapai $80,76 \%$. Hasil yang demikian itu juga tidak lepas dari peran berbagai pihak yang mampu membangun koordinasi secara tepat. Namun, tujuan yang mulia tentang pembentukan relawan demokrasi itu menjadi kurang relevan ketika secara hukum, terdapat masalah dari aspek pembentukannya. Apalagi pada tatanan pelaksanaannya telah menimbulkan implikasi tersendiri, yang tentunya diakibatkan dari ketidakjelasan dan disharmonisasi norma hukum pembentukannya.

Mempertegas kembali bahwa secara normatif pembentukan relawan demokrasi tidak sesuai dengan ketentuan peraturan perundang-undangan. Terdapat suatu disharmonisasi peraturan, yang justru dipaksakan untuk tetap dilanjutkan. Pemberian kewenangan melalui sebuah surat oleh KPU (Pusat), juga tidak dapat dibenarkan secara hukum, khususnya dari perspektif teori kewenangan maupun teori pembentukan peraturan perundang- undangan. Suatu surat yang dikeluarkan oleh lembaga negara, bukan termasuk dalam peraturan perundang-undangan, apalagi difungsikan sebagai dasar pembentukan kewenangan untuk membentuk sebuah badan ad-hoc, yaitu relawan demokrasi.

Apabila ditelaah, terdapat beberapa implikasi yang ditimbulkan sebagai akibat disharmonisasi tersebut. Pertama, adanya ketidakjelasan kedudukan dalam lingkup KPU. Pasal 6 UU No. 7 Tahun 2017 telah menegaskan bahwa KPU terdiri atas KPU (Pusat), KPU Provinsi, KPU Kabupaten/Kota, PPK, PPS, PPLN, KPPS, dan KPPSLN. Berdasar pada ketentuan tersebut, tidak disebutkan letak atau kedudukan relawan demokrasi. Padahal jika melihat pada aspek pembentukannya, relawan demokrasi dibentuk oleh KPU, khususnya pada tingkat KPU/KIP Kabupaten/Kota. Sama halnya dengan, misalnya PPK, PPS atau KPPS, yang juga dibentuk oleh KPU/KIP Kabupaten/Kota.

Sebagai salah satu contoh kasus yang terjadi di wilayah Kabupaten Pasuruan. Pada saat proses awal bimbingan teknis yang dilansungkan, pihak KPU Kabupaten Pasuruan, belum mampu menjelaskan kedudukan relawan demokrasi secara hirarkis. Barulah setelah lewat beberapa waktu, dikonfirmasi oleh KPU bahwa kedudukan relawan demokrasi adalah sebagai mitra KPU yang mempunyai hubungan langsung dengan KPU, khususnya dari 
segi pertanggungjawaban. Penjelasan itu muncul akibat adanya persoalan mengenai kedudukan relawan demokrasi dengan PPK di wilayah Kabupaten Pasuruan. PPK menganggap bahwa relawan demokrasi bertugas dibawah naungan PPK, dan bertanggungjawab kepada PPK. Padahal, maksud dari pembentukan relawan demokrasi adalah langsung dibawah KPU Kabupaten/Kota. Kondisi demikian ini sempat menimbulkan ketegangan. Apalagi relawan demokrasi mempunyai anggaran tersendiri yang harus dipertanggungjawabkan kepada KPU Kabupaten Pasuruan untuk melaksanakan sosialisasi pemilu dan pendidikan pemilih, sedangkan PPK tidak lagi mempunyai anggaran untuk melakukan sosialisasi itu. Kedudukan yang semacam ini bahkan tidak dijelaskan baik dalam peraturan KPU, maupun pada surat yang dikeluarkan oleh KPU, berikut dengan lampirannya. Kedudukan tersebut dapat digambarkan sebagai berikut:

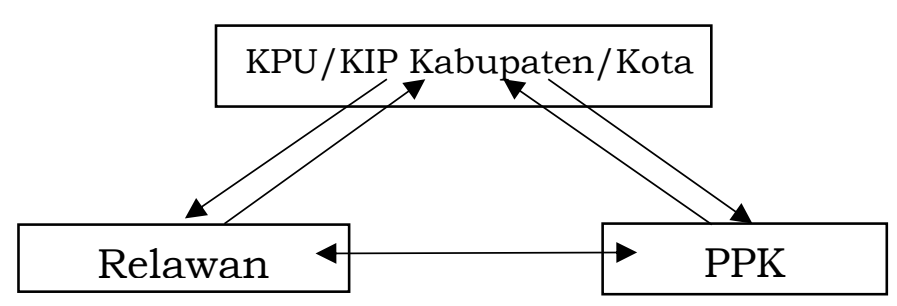

Berdasar pada gambar tersebut, dipahami bahwa KPU pada tingkat Kabupaten/Kota, mempunyai kedudukan yang tinggi. Berperan sebagai penanggungjawab tugas relawan demokrasi. Namun, secara struktural, relawan demokrasi tidak berada dalam lingkup struktural KPU atau bahkan masuk sebagai unsur penyelenggara pemilu. Uniknya, kedudukan antara relawan demokrasi dengan PPK, adalah sejajar. Relawan demokrasi melakukan koordinasi dengan PPK, khususnya dalam melakukan kegiatan sosialisasi. Relawan demokrasi, maupun PPK mempunyai tugas masing-masing, dan bersifat independen.

Hanya saja, kondisi yang demikian itu tidak ditegaskan secara normatif dalam berbagai peraturan perundang-undangan, ataupun dalam peraturan kebijakan. Kondisi struktural tersebut justru dipahami dalam tatanan pelaksanaannya. Tidak heran jika kemudian pada tatanan pelaksanaannya justru menimbulkan konflik secara horizontal maupun vertikal, yaitu relawan demokrasi dengan KPU, atau bahkan relawan demokrasi dengan PPK.

Kedua, ketidakjelasan tugas, wewenang dan pertanggungjawaban. Apabila membandingkan dengan, misalnya PPK, PPS, maupun juga KPPS, terdapat ketentuan yang secara jelas dan berkepastian perihal tugas, wewenang, maupun kewajibannya dalam UU No. 7 Tahun 2017. Menjadi suatu hal yang kontradiksi, dan menimbulkan suatu problematika baru jika tugas yang melekat pada relawan demokrasi hanya dituangkan melalui surat dan sebuah pedoman teknis, yang tidak mempunyai 
kekuatan mengikat dan keberlakuan secara hukum. Padahal peran relawan demokrasi sangat krusial, dengan berhadapan langsung kepada masyarakat yang mempunyai hak pilih.

Secara umum mereka berperan untuk menyampaikan materi (melakukan sosialisasi), tentang penyelenggaraan pemilu dan pendidikan pemilih. Bahkan dalam pedoman teknis juga disebutkan bahwa relawan demokrasi juga melakukan peragaan atau simulasi teknis tentang pemilu.

Peran krusial ini, tentu dimaksudkan sebagai langkah meningkatkan partisipasi masyarakat dalam menyalurkan hak pilinnya, maka idealnya perlu dikonstruksikan dalam aturan yang lebih mempunyai daya ikat dan ada kepastian hukum. Dasar teori kepastian hukum menekankan bahwa, "the principle of legal certainty requires that rules of law be clear and precise and predictable in their effect, so that interested parties can ascertain their position in situations and legal relationships". ${ }^{16}$ Dapat dipahami bahwa melalui adanya kepastian hukum dapat diperoleh tata hubungan yang jelas, termasuk berkaitan dengan tugas, kedudukan hingga pada pertanggungjawabannya.

Ketiga, berdasar pada surat KPU Nomor: $\quad 32 / P P .08-S D / 06 / K P U / / / 2019$, tertanggal 9 Januari 2019, secara jelas

${ }^{16}$ Pablo Martin Rodriguez, 2015, "The Principle Of Legal Certainty And The Limits To The Applicability mengarahkan kepada KPU/KIP Kabupaten/Kota untuk membentuk relawan demokrasi. Namun, tidak pernah ada ketentuan lebih lanjut mengenai mekanisme pembubarannya. Padahal relawan demokrasi ini bukanlah suatu badan/kelompok permanen, sehingga perlu juga dilakukan pembubaran, baik secara de facto, melalui proses seremoni sebagaimana ketika awal pembentukkannya, maupun de jure melalui peraturan KPU/KIP Kabupaten/Kota. Salah satu kasus yang terjadi adalah di KPU Kabupaten Pasuruan, sejak adanya pengumaman KPU Kabupaten Pasuruan Nomor: 090/PP.08.Pu/3514/KPU-Kab/l/2019 tentang Penetapan Hasil Seleksi Relawan Demokrasi 2019, dan dilanjutkan dengan Pengukuhan pada tanggal 23 Januari 2019, sebagaimana dimuat dalam surat KPU Kabupaten Pasuruan Nomor: 099/PP.07Und/3514/KPU-Kab//2019, sampai dengan pelaksanaan pemilu 17 April 2019, serta dua bulan setelah tanggal pemilu tersebut, belum pernah dilangsungkan pembubaran relawan demokrasi. Artinya, sampai tulisan ini disusun, menandakan bahwa relawan demokrasi KPU Kabupaten Pasuruan, masih terikat baik hak dan kewajibannya. Berbeda dengan misalnya PPK, PPS ataupun KPPS, yang ada mekanisme

Of EU Law", Cahiers De Droit Europeen Vol. 10, hal. 117 
serta prosesi pembentukan dan pembubaran.

Kondisi demikian ini jelas semakin memperkuat bentuk disharmonisasi pengaturan mengenai pembentukan relawan demokrasi. Hal ini bukanlah sesuatu yang dapat diremehkan, sebab dapat memunculkan efek domino, khususnya dalam kaitan dengan kredibilitas sebuah lembaga negara.

Berdasar pada implikasi inilah, maka dalam tatanan pembangunan hukum ke depan (ius constituendum), perlu diperhatikan kembali mengenai aspek fundamental, khususnya dalam melakukan pembentukan sebuah badan ad-hoc di lingkungan KPU, seperti halnya relawan demokrasi. Pertama, berkaitan dengan landasan hukum (aspek yuridis). Mengingat bahwa Indonesia adalah negara hukum, maka setiap pembentukan kelembagaan, baik yang bersifat ad-hoc maupun permanen, haruslah dilandasi peraturan perundangundangan. Adanya regulasi yang jelas (legal certainty), menjadikan tugas, fungsi dan kedudukan relawan demokrasi dalam penyelenggaraan pemilu 2019 menjadi jelas dan tegas. Hal ini juga meminimalisir adanya konflik dalam pelaksanaannya. Perumusan regulasinya idealnya dibentuk pada satu Pasal dalam undangundang atau peraturan pemerintah. Mempunyai relevansi dengan pelaksanaan sosialisasi pemilihan umum. Kedua, mempertegas dan memperjelas struktural kelembagaannya.
Sekalipun sifatnya adalah ad-hoc, secara struktural harus dirumuskan kedudukannya, termasuk pola hubungan dengan penyelenggara pemilu yang lain. Mengingat bahwa relawan demokrasi mempunyai peran yang cukup signifikan dalam penyelenggaraan pemilu, maka idealnya relawan demokrasi dimasukkan juga sebagai penyelenggara pemilu dalam UU Pemilihan Umum.

Tidak menutup kemungkinan pula untuk melakukan perubahan UU No. 7 Tahun 2017 dengan memasukan relawan demokrasi sebagai bagian dari KPU, guna memberikan kepastian hukum. Termasuk memberikan konstruksi yang jelas mengenai tugas, wewenang, kewajiban dan tanggungjawabnya. Apalagi jika mengingat bahwa secara filosofis, maupun sosiologis keberadaan relawan demokrasi mampu memberikan sumbangsih untuk meningkatkan partisipasi masyarakat dalam pemilu. Relawan demokrasi tidak sekedar menjadi "hantu" dalam penyelenggaraan pemilu, tetapi mampu menjadi pioneer dalam memajukan dan meningkatkan partisipasi pemilu di berbagai periode. Memperkuat legitimasi kehadiran relawan demokrasi, secara tidak langsung juga memperkuat dasar demokrasi dalam bingkai kedaulatan rakyat.

\section{Penutup}

Salah satu upaya yang dilakukan untuk mensukseskan pemilihan umum serentak adalah melalui pembentukan 
relawan demokrasi. Namun ternyata, setelah melakukan telaah ditemukan adanya disharmonisasi pengaturannya, khususnya pada aspek pembentukan dan kedudukannya. Surat Komisi Pemilihan Nomor: $\quad 32 / P P .08-S D / 06 / K P U / / / 2019$, tertanggal 9 Januari 2019 tidak dapat menjadi dasar dalam memberikan kewenangan kepada KPU/KIP Kabupaten/Kota untuk membentuk relawan demokrasi. Hal ini yang kemudian juga berdampak pada disharmonisasi kedudukan relawan demokrasi dengan badan ad-hoc lainnya, seperti PPK atau PPS.

Selain itu, akibat adanya disharmonisasi ini muncul beberapa implikasi. Pertama, adanya ketidakjelasan kedudukan relawan demokrasi dalam lingkup Komisi Pemilihan Umum, khususnya pada tingkat Kabupaten/Kota. Kedua, ketidakjelasan tugas, wewenang dan kewajiban yang diberikan kepada relawan demokrasi. Ketiga, ketidakjelasan status relawan demokrasi akibat tidak adanya proses dan dasar pembubaran yang jelas. Berdasar pada uraian tersebut, maka perlu dilakukan pembenahan, baik secara yuridis maupun kelembagaan. Hal ini dimaksudkan untuk memperjelas dan mempertegas kedudukan relawan demokrasi sebagai penyelenggara pemilu.

\section{Bibiliografi}

Buku:

Anwar C., 2008. Teori dan Hukum Konstitusi Paradigma Kedaulatan Pasca Perubahan UUD 1945, Implikasi dan Implementasinya Pada Lembaga Negara, Malang: In-Trans Publishing.

Jimly Asshiddiqie. 2005. Hukum Tata Negara dan Pilar-Pilar Demokrasi, Jakarta: Konstitusi Press.

Jimly Asshiddiqie. 2010. Perkembangan \& Konsolidasi Lembaga Negara Pasca Amandemen. Jakarta: Sinar Grafika.

Janedrji M. Gaffar. 2010. Hukum Acara Mahkamah Konstitusi. Jakarta: Sekretariat Jenderal dan Kepaniteraan Mahkamah Konstitusi.

Komisi Pemilihan Umum. 2019. Pedoman Pelaksanaan Relawan Demokrasi (Relasi) Pemilu Tahun 2019. Jakarta: Komisi Pemilihan Umum.

Philupus M. Hadjon, et.all. 2008. Pengantar Hukum Administrasi Indonesia, Introduction to the Indonesian Administrative Law, Yogyakarta: Gadjah Mada University Press.

Sirajuddin, et.all. 2016. Legislative Drafting, Pelembagaan Metode Partisipatif dalam Pembentukan Peraturan Perundanga-undangan. Malang: Setara Press.

Suparno, et.all. 2010. Pemilu Untuk Pemula. Jakarta: Komisi Pemilihan Umum.

Soerjono Soekanto dan Sri Mamudji. 2006. Penelitian Hukum Normatif (Suatu Tinjauan Singkat). Jakarta: PT Raja Grasindo Persada.

Tegus Prasetyo. 2018. Filsafat Pemilu. Bandung: Nusa Media. 


\section{Jurnal:}

Pablo Martin Rodriguez. 2015. "The Principle Of Legal Certainty And The Limits To The Applicability Of EU Law", Cahiers De Droit Europeen, Vol. 10.

Ria Casmi Arrsa. 2014. "Pemilu Serentak dan Masa Depan Konsolidasi Demokrasi”. Jurnal Konstitusi, Vol. 11, No. 3.

\section{Internet:}

Anonim, "Surat Edaran Bukan Peraturan Perundang-Undangan", <https://www.hukumonline.com/berita /baca/hol18765/surat-edaran-bukanperaturan-perundangundangan/>, diakses 16 Maret 2008. 